\title{
Ambuláns versus otthoni telemonitorozott tréning. A választást befolyásoló tényezök
}

\author{
Ábrahám Erzsébet Judit', Máthéné Köteles Éva2,3, Korom Andrea², \\ Vágvölgyi Anna", Szúcs Mónika ${ }^{5}$, Rafael Beatrix', Lengyel Csaba ${ }^{4}$, \\ Barnai Mária², Kósa István ${ }^{1}$
}

\author{
'SZTE ÁOK, Preventív Medicina Tanszék, Szeged, ${ }^{2}$ SZTE ETSZK Fizioterápiás Tanszék, Szeged \\ ${ }^{3}$ SZTE ÁOK, Interdiszciplináris Doktori Iskola, Szeged, “SZTE ÁOK, Belgyógyászati Klinika, Szeged \\ ${ }^{5}$ SZTE ÁOK, Orvosi Fizika és Orvosi Informatika Intézet, Szeged
}

Levelezési cím:

Dr. Kósa István, SZTE ÁOK, Preventív Medicina Tanszék, 6720 Szeged, Korányi fasor 8-10

E-mail: office.prevmedicina@med.u-szeged.hu

Bevezetés: A fejlett világ országaiban a Metabolikus Szindróma (MetS) a népesség mintegy negyedét érinti. A MetS kezelésének a kulcsa az életmódváltás, különös tekintettel a tréning jellegű fizikai aktivitás felépítésére.

Célkitűzés: Annak felmérése, hogy a különböző intézeti, illetve a beteg otthonában működő szívfrekvencia-monitorozó rendszerekkel milyen karakterisztikájú betegekben, illetve milyen volumenű monitorozott tréning valósítható meg?

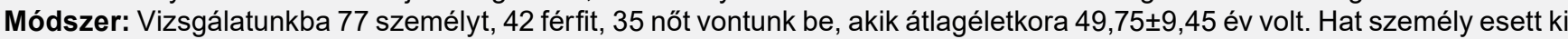
az intervenció előtt. A vizsgálati protokoll megengedte a betegek preferenciájának figyelembe vételét a vizsgálati ágakra való bevonáskor, így az ambuláns intézeti tréning („A”) ágra 15, a mellpántos („M”) elektromos otthoni monitorozási ágra 33, az okosórás (,O”) optikai rendszerrel otthonában monitorozott ágra 23 beteg került. A betegekkel az állapotfelmérést követően gyógytornász egyénileg egyeztetett a hét 3-5 napján elvégzendő, heti minimum 150 perc időtartamú tréningekről. A tréningeket a gyógytornász heti rendszerességgel a távolból ellenőrizte, konzultálta. A bejárós csoport tagjaitól minimum heti két csoportos tréningen való részvételt kértünk.

Eredmények: A vizsgálatot 15 bejárós, 31 mellpántot és 21 okosórát viselő személy vitte végig. Úgy az „M”, mint az „O” ágból

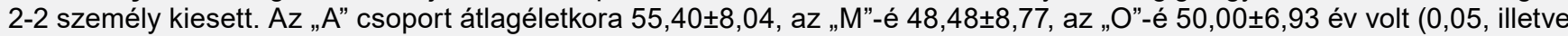
$<0,01$ vs. „A”). A vizsgálatra került betegek lakhelyének távolsága a vizsgálati helyszíntöl a „A” csoport esetében $3,90 \pm 2,00$,

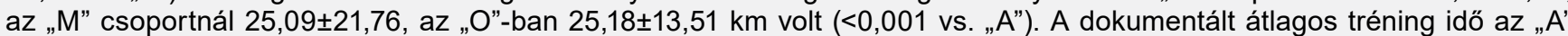

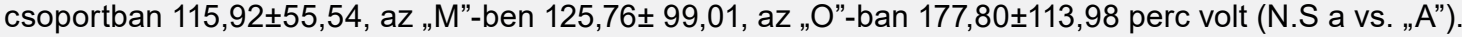

Következtetés: A jelentős részben aktív korosztályba tartozó metabolikus szindrómás személyek között a telemonitorozott tréning szélesebb körben elfogadott, mint a bejárós intézeti tréning. Az intézeti tréningre jellemzően a helyben lakó, korosabb korcsoport kapható.

Kulcsszavak: fizikai tréning, telemonitorozás, metabolikus szindróma

Outpatient versus home monitored training. Factors affecting patient preferences

Background: In the developed world Metabolic Syndrome affects a quarter of the population. The key to the treatment of these patients is the change of lifestyle, in particular the development of the physical activity.

Aims: To evaluate the characteristics of patients who underwent institutional as well as home-based heart rate monitored training and assessed the achieved training volume with different interventions.

Method: The study involved 77 patients, 42 men, and 35 women. The average age was $49.75+9.45$ years. There were 6 patients dropped out before the intervention. The study protocol allowed to accept patient preference at the selection of training locations and devices used for monitoring. 15 patients were involved in the "A", ambulatory training group, 33 in the "M", cheststrap based home-monitored group, while 23 in the "O", smartwatch based home-monitored group. After a health check, a physiotherapist individually consulted with the patients about the training forms, covering at least 3 episodes per week with a total duration of 150 minutes. The training was remote-monitored and consulted every week. Patients in the institutional group participated in institutional training at least 2 times per week.

Results: The study was completed by 15, 31 and 21 patients in the "A", "M" and "O" groups, respectively. There were 4 patients dropped out: 2-2 patients form the "M" and "O" groups. The average age of the patients in the group "A", "M" and "O" were 55.40+ 8.04, 48.48+8.77 and $50.00+6.93$, respectively ( $p<0.05$ for " $M$ " and $<0.01$ for "O" vs. " $A$ "). The distance of the patients' home from the location of the institution were $3.90+2.00,25.09+21.76$ and $25.18+13.51 \mathrm{~km}$, respectively ( $<<0.001$ for "O" and "M" v.s. "A"). The documented duration of the trainings were $115.92+55.54 ; 125.76+99.01$ and $177.80+113.98$ minutes, respectively ( $p<0.05$ for "O" vs. "A" and "M").

Conclusion: Remote-monitored training is preferred by the Metabolic Syndrome patients of active age bracket comparing the institutional training. The older and resident patients choose typically the institutional training.

Keywords: exercise training, remote patient monitoring, metabolic syndrome

A kézirat 2020. 09. 01-jén érkezett a szerkesztőségbe, 2020. 10. 21-én került elfogadásra. 


\section{Bevezetés}

Közismert, hogy az egészségügyi ellátások súlypontja a XXI. századra átstrukturálódott, fókusza az infekciók, sérülések ellátása felöl a hosszú távú ellátást igénylő, úgynevezett nem fertőző betegségekre („non-communicable diseases") - mint a cukorbetegség, magas vérnyomás, érbetegségek, illetve az onkológiai betegségekre helyeződött át. Az ilyen hosszú lefolyású betegségek ellátása köti le az egészségügyi költségvetés meghatározó részét, amerikai adatok szerint $75 \%$-át (1). Bár a civilizációs betegségek kialakulásában, illetve lefolyásában meghatározó szerepet játszik a betegek életmódja (2), a modern, „nyugati típusú” orvoslásban ezen tényezők uralása mégis háttérbe szorult, fókuszban a gyógyszeres és eszközös beavatkozások állnak. $A z$ életmód-változtatás fontosságával ugyan minden szakember egyetért, de az életmód-átalakításra szoruló betegek meghatározó része csak 2-3 perces, rövid orvosi tanácsadásban részesül az életmód-átalakításra vonatkozóan, amelynek hatása bizonyítottan igen gyenge (3). A táplálkozási szokások, a hétköznapi fizikai aktivitásszint módosítására ennél lényegesen hoszszabb, intenzívebb intervencióra van szükség $(4,5)$.

Hazánk fekvőbeteg-súlypontú rehabilitációs ellátóinak palettáján megjelennek ugyan ezen krónikus betegségben szenvedő, magas kardiovaszkuláris rizikójú betegek is, ezen fekvőbeteg-kapacitások alapvetően a már dokumentált szívbetegek ellátásával vannak lekötve. Az elmúlt évtizedben számottevő ambuláns rehabilitációs kapacitásfejlesztés történt hazánkban, ezen kapacitások azonban relatíve kis volumennel müködnek, alapvetően az életképes finanszírozás hiánya miatt. Hasonlóan igen alacsony volumenủ az az ellátói kapacitás, amely az Egészségfejlesztési Irodák rendszere révén célozza a magas kockázati személyek rizikócsökkentését életmódi intervenciókkal.

A fenti fekvő, illetve ambuláns életmódi intervenciók egy ígéretes kiegészítője lehet a telemonitorozott otthoni tréning, amikor a beteg saját otthoni környezetében végez monitorozott fizikai aktivitást, az aktivitásszint azonos idejü (szinkron/,online”), vagy időben eltolt (aszinkron/,store-and-forward”) leképezésével. A szinkronmonitorozási technika jelentős költségek árán mérsékelt biztonsági nyereséget mutat fel, hiszen a monitorozást vezető személy beavatkozási lehetőségei erősen korlátozottak. A beteg felé adott utasítások révén a tréningintenzitás ugyan valós időben kormányozható, de az esetleges szövődmények elhárítására is alapvetően csak ezen csatorna használható. A legkritikusabb, iszkémiás szövődmények időfaktora ugyanis jelentősen magasabb annál, mint amit külső segítség bevonásával a távolból le lehet kezelni.

Ezen megfontolások miatt a tréningmonitorozás szélesebb körben alkalmazott technikája a kisebb humán- és technikai költségek mellett megszervezhető aszinkronmonitorozás. Ennél a monitorozási módnál a beteg magának választhatja meg a tréning végzésének időpontját, nem kell alkalmazkodnia a monitorozó időbeosztásához, a monitorozó pedig relatíve kisebb időráfordítással át tudja tekinteni az egyes tréningek aggregált adatait, szokásos munkarendjébe szabadon beillesztve ezen tevékenységet. Az aggregált adatok alapján tréningröl tréningre tud iránymutatást adni a vezetett betege számára. Úgy a szinkron, mint az aszinkron tréningmonitorozás pozitív hatással van a tréningek megvalósulására, azaz a terápiás adherenciára, hiszen önmegában a kontroll tudata növeli a monitorozott személy eltökéltségét a vállalt tréningek végrehajtására. Mivel ezen aszinkronmonitorozásnak nem tárgya a ritmuszavarok detektálása, a monitorozás eszközrendszereként olcsóbb szívfrekvencia-monitorok is használhatók a drága, minimum egy csatornás, EKG adatátviteli rendszerek helyett.

Aszinkron szívfrekvencia monitorozásra épülő otthoni tréninggel vizsgálatokat a Szegedi Tudományegyetemen 2018-ban indítottunk el, két különböző otthoni monitorozási szettet alkalmazva, egy harmadik betegcsoportban pedig a betegek számára intézeti ambuláns tréninget felajánlva. A vizsgálat során a vizsgálati ágakra való véletlenszerü betegbesorolásra törekedtünk, de elfogadtuk a beteg esetleges diszprefrerenciáit egyes vizsgálati ágakkal kapcsolatban.

Jelen munkánk célja annak felmérése, hogy a betegek egyéni paraméterei milyen összefüggésben állnak a tréningmodalitás megválasztásával?

\section{Beteganyag és módszer}

A vizsgálatba 25 és 70 év közötti életkorú, alacsony szintű fizikai aktivitású (heti 30 percnél kevesebb tréning) metabolikus szindrómás betegeket vontunk be. A metabolikus szindróma definíciójára az ATP-III kritériumokat használtuk (6), azaz a betegeknek az alábbi 5 kritériumából minimum 3 rizikótényezővel rendelkezniük kellett:

1. derékbőség férfiaknál $102 \mathrm{~cm}$ felett, nőknél $88 \mathrm{~cm}$ felett,

2. kezelt 2-es típusú cukorbetegség vagy éhomi vércukorszint $5,6 \mathrm{mmol} / \mathrm{l}$ felett,

3. kezelt magas vérnyomás vagy spontán $130 / 85$ Hgmm feletti vérnyomás,

4. fibrátkezelés vagy $1,7 \mathrm{mmol} / \mathrm{l}$ feletti szérum trigliceridszint,

5. szérum HDL-koleszterin-szint férfiaknál $1,03 \mathrm{mmol} / \mathrm{l}$ alatt, nőknél 1,3 $\mathrm{mmol} / \mathrm{l}$ alatt.

Kizárási kritériumok az alábbiak voltak: tervezett invazív kardiológiai beavatkozás (katéteres értágítás vagy mütéti koszorúér-áthidalás, billentyüplasztika vagy csere), nem kontrollált magas vérnyomás (RR>160/100), 1-es típusú cukorbetegség, napi egynél több inzulindózissal kezelt 2-es típusú cukorbetegség, szívelégtelenség, veseelégtelenség (eGFR $<60 \mathrm{ml} / \mathrm{min}$ ), tumoros megbe- 
tegedés, súlyos kognitív diszfunkció, kooperációhiány, ismert, a fizikai tréning kivitelezését megakadályozó állapot, illetve a belátóképességet, cselekvőképességet súlyosan befolyásoló állapot.

\section{Kezdeti és záró állapotfelmérések}

A kezdeti és záró orvosi vizsgálatok a Szegedi Tudományegyetem, Általános Orvostudományi Kar, 1. sz. Belgyógyászati Klinikáján, míg a gyógytornászfelmérések és az intézeti tréningek a Szegedi Tudományegyetem Egészségtudományi és Szociális Képzési Kar, Fizioterápiás Tanszékén történtek. Az indulási vizsgálatok maximum 4 héttel a tréning megkezdése előtt, a záró felmérések pedig a 12 hetes tréning befejezése utáni 4 hétben történtek. Az orvosi vizsgálat során áttekintésre és dokumentálásra kerültek a betegek aktuális panaszai, kórtörténete, laborvizsgálati eredményei, aktuális gyógyszeres terápiája és fizikális státusza, ellenőrzésre kerültek bevonási és kizárási kritériumai. Az első vizsgálatkor rutin kardiológiai echokardiográfiás vizsgálat készült Vivid-e (Boston, Massachusetts, USA) ultrahangkészülékkel a fizikális terhelhetőséget esetlegesen befolyásoló eltérések beazonosítására.

\section{Terheléses EKG-vizsgálat}

12 csatornás nyugalmi EKG-vizsgálat (CardioSys, MDE Diagnostic, Walldorf, Germany) után lépcsőzetesen növekvő intenzitású terheléses EKG-vizsgálat történt a módosított Bruce Protokoll szerint a 220 - életkor alapján kalkulált maximális szívfrekvenciáig, vagy a beteg kimerüléséig. Az elért maximális terhelhetőség METben kifejezve $(\mathrm{ml} / \mathrm{kg} / \mathrm{min})$, a maximális szívfrekvencia (bpm) és a maximális terhelés eléréséig eltelt idő (s) kerültek dokumentálásra.

\section{Funkcionális kapacitás mérése}

Az alanyok funkcionális kapacitását a 6 perces járásteszttel (6MWT) mértük fel, egy 30 méteres, méterenként beosztott kültéri pályán az ATS (American Thoracic Society) irányelve szerint $(4,5)$. A 6 perc alatt megtett távolságot $(\mathrm{m})$, illetve a módosított Borg-skálán (0-10) elért szubjektíven megélt kifáradás mértékét dokumentáltuk.

\section{Intervenció}

Az állapotfelmérés után a betegeket különböző formában monitorozott tréningcsoportokba soroltuk be:

- „A" csoport: ambuláns intézeti tréning.

- „M” csoport: elektromos pulzusszámoló mellpántot és mobiltelefont használó otthoni tréning.

• „O” csoport: optikai pulzusszámoló „okosórát” használó otthoni tréning.

A betegek besorolása az egyes vizsgálati ágakra véletlenszerüen történt. Egy gyüjtőben elhelyezett borítékok kihúzása random sorrendben történt. Amenynyiben egy beteg valamely típusú intervenciós ághoz való csatlakozást nem tudta vállalni, például a cso- portos tréningekre való rendszeres beutazás földrajzi akadálya miatt, vagy az eszközök önálló használatának elutasítása miatt, azt a kartonján jeleztük, és a beteg számára addig húztunk új borítékokat, amíg a számára elfogadható két ág valamelyikébe való besorolást biztosítani tudtuk. A fel nem használt borítékok a gyüjtöbe visszakerültek.

\section{${ }_{9} \mathrm{~A}$ gyógytornászok által vezetett intézeti ambuláns tréning}

Az intézeti bejárós csoport tagjai hetente kétszer 45-60 perces gyógytornászok által vezetett csoportos tréningen vettek részt. Az egyik fizikai tréningalkalom alapvetően dinamikus, aerob állóképességi típusú edzésből állt, amely egy 8-10 perces bemelegítést, futópados, kerékpár-ergométeres, ellipszistréneres-edzést és levezetést tartalmazott köredzés formájában. A másik tréningalkalom során föleg rezisztenciatípusú edzés zajlott szintén körtréning formában, amely bemelegítésből, kombinált alsó- és felsővégtagi izmokat erősítő, saját testsúlyos és súlyzós/eszközös edzésböl, illetve levezetésböl állt. Az intézeti tréningen résztvevők szívfrekvenciáját a Polar Team Pro System (Kempele, Finnország) rendszerrel és a hozzá tartozó elektromos mellpántokkal monitoroztuk. Ez a rendszer alkalmas a csoport összes tagjának egyidejü szívfrekvencia-mérésére és megjelenítésére az adott csoportos tréning során, így a gyógytornász folyamatosan nyomonkövetheti a pulzusgörbék változását. Emellett további heti egy alkalommal arra kértük a betegeket, hogy otthoni környezetükben, egy minimum 30 perces tréninget végezzenek szabadon választott fizikai aktivitásformával, de ezen tréning megtörténtét a vizsgálat során nem ellenőriztük.

\section{${ }_{g} M^{\prime \prime}$ mellpántos elektromos szenzorra}

telemonitorozott, önálló otthoni tréning

A résztvevők az állapotfelmérést követően a gyógytornászoktól részletes tájékoztatást kaptak a 12 hétig tartó otthoni tréningprogramról, a kiadott eszközök használatáról, a tréningkövetés és a szükséges adatfeltöltés menetéről. A résztvevőktől azt kértük, hogy heti 3-5 alkalommal (minimum 30 percig) végezzenek fizikai tréninget önállóan, a nemzetközi irányelvekben előírt heti minimum 150 perces időtartamot célozva és azt meghaladva $(6,7)$. Bármilyen típusú fizikai tréninget végezhettek, de előzetesen tájékoztatást kaptak arról, hogy milyen tréningformák/fizikai aktivitások ajánlottak metabolikus szindróma esetén. A fizikai aktivitások során elérendő és tartandó célszívfrekvencia-zónát minden résztvevőnél egyénileg határoztuk meg a maximális terhelhetőséget figyelembe véve, az életkori maximális szívfrekvencia $60-80 \%$ között.

Az "M" csoportban az alanyok elektromos szívfrekvencia-monitorozó mellpánt (Polar H10, Kempele, Finnország) használatát vállalták otthoni tréningjeik során, amelynek adatgyűjtéséhez egy párosított and- 
roidos mobiltelefont (Meizu M5c, Kína) is biztosítottunk. A monitorozás a készülékre elöre letöltött ingyenes applikáción (Polar Beat) keresztül volt indítható, illetve leállítható. A tréningidő, a megtett távolság, az intenzitás és a pulzuszónák alakulását az applikáción keresztül a résztvevők a tréning közben folyamatosan ellenőrizhették, míg a tréning befejezésével a rendszer az adatokat automatikusan szinkronizálta a hozzá integrált felhőszolgáltatásba (https://flow.polar.com és https://flow.polar.com/coach). A gyógytornászok az adatokat tetszőleges browserből, a távolból tudták ellenőrizni és heti rendszerességgel konzultáltak, tartották a kapcsolatot a résztvevőkkel ezen rendszer üzenetablakán, vagy telefonon/e-mailen keresztül.

\section{"O" optikai szenzorral telemonitorozott, önálló otthoni tréning}

A „O” csoport alanyai az otthoni tréningek során optikai szívfrekvencia-monitorozó karórát (Polar M430 GPS running watch, Kempele, Finnország) viseltek, amely eszköz képes a tréning önálló indítására és leállítására, de az adatok szinkronizálása nem történik automatikusan. Az adatok vezeték nélküli (Bloototh) vagy vezetéken keresztüli szinkronizálása a felhőszolgáltatás irányába a betegek önálló interakcióját igényelte egy saját tulajdonú, saját internetkapcsolatú androidos mobiltelefonon/laptopon/PC-n futó applikáció (Polar Flow) révén.

$\mathrm{Az}$ „O” csoport az otthoni tréningek végrehajtására egyebekben teljesen azonos utasítást kapott, mint az „M" csoport tagjai.

\section{Lakóhelly távolságának számítása}

A vizsgálatban résztvevők lakhelyét a felvételkor utca, házszám pontossággal rögzítettük. Ezen lakhely távolságát az ambuláns intézeti tréning helyszínétöl (Szeged, Temesvári krt. 31.) google map (www://goolge.com/maps Google Inc. Mountain View, CA, USA), autós útvonaltervezőjével számítottuk. A távolság meghatározásakor a km-ben meghatározott legrövidebb útvonalat vettük figyelembe minden betegnél.

\section{Statisztikai módszerek}

Az adatokat átlag \pm szórás $(S D)$ formában adtuk meg. A csoportok összehasonlítására két mintás T-próbát használtunk. A statisztikai elemzéshez $R$ statisztikai szoftvert használtunk (R version 3.6.2, https:// www.r-project.org/), a $p<0,05$ értéket tekintettük statisztikailag szignifikánsnak. A vizsgálatot az ETT TUKEB engedélyezte. Az etikai engedély szám 507802/2017EKU

\section{Eredmények}

Vizsgálatunkba 77 személyt, 42 férfi, 35 nőt vontunk be, akik átlagéletkora 49,75 $\pm 9,45$ év volt. Az induló betegvizsgálat után, még a monitorozás elindulta előtt 6 személy esett ki a vizsgálatból. A kiesés oka két esetben a vizsgálat során feltárt kóros állapot (effort angina, illetve újkeletű pitvarfibrilláció), négy esetben a beteg beleegyezésének visszavonása volt. Mivel a protokoll megengedte a vizsgálati ágak diszpreferált választását a betegek számára, az egyes vizsgálati ágak esetszáma eltérő volt. A kialakult arány a következőképpen alakult: 15, 33, 23 az „A”, „M”, illetve „O” csoportok vonatkozásában. Ahogy az 1. táblázat ezt résztelesen bemutatja, az „A”, bejárós csoport női dominanciájú, míg az otthoni csoportokban a férfidominancia a jellemző. A bejárós „A" csoport tagjai szignifikánsan idősebbek a bejárást vállaló csoportok tajgainál. $A$ testtömeg és a testtömegindex vonatkozásában nem alakult ki különbség a csoportok között, 6 perces járástesztje az egyes csoportba kerülőknek érdemben nem különbözött. A terheléses EKG során ugyanakkor a bejárós, korosabb csoport szignifikánsan kisebb terhelési szintet ért le, standardizált terhelési protokoll mellett rövidebb volt a maximális terhelhetőség eléréséig eltelt idejük. $A z$ utóbbi két változóban szignifikánsnak mutatkozott a különbség a relatíve fiatalabb „M” csoport és az idősebb "O" csoport tagjai között is.

Az egyes csoportokba tartozó személyek lakhelyének távolságát a csoportos intézeti tréning helyszínétöl az 1. ábra mutatja. $\mathrm{A} z$ „A” csoport esetében ez a távolság

1. TÁBLÁZAT. Az egyes csoportok betegeinek antropometriás és funkcionális adatai a vizsgálat indulásakor. "A" = ambuláns intézeti rehabilitáció, „M" = mellpántos otthoni rehabilitáció, "O” = optikai szenzoros „okosórás” otthoni rehabilitáció. BMI = testtömegindex, $6 \mathrm{MWD}=6$ perces járótávolság, MET = metabolikus ekvivalens, TEKG-idő = terheléses EKG-n a maximális terhelés eléréséig eltelő idő (értékek átlag \pm SD)

\begin{tabular}{|c|c|c|c|c|c|c|}
\hline & "A" & ,A" vS. M" & ,M" & "M" vs. "O", & ,0" & 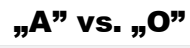 \\
\hline Fő (férfi/nő) & $15(10 / 5)$ & & $31(20 / 11)$ & & $21(14 / 7)$ & \\
\hline Kor (kg) & $55,40 \pm 8,04$ & $p<0,001$ & $48,48 \pm 8,77$ & ns. & $50,00 \pm 6,93$ & $p<0,05$ \\
\hline Testtömeg (kg) & $95,51 \pm 22,30$ & ns. & $94,09 \pm 18,18$ & ns. & $103,33 \pm 23,01$ & ns. \\
\hline BMI $\left(\mathrm{kg} / \mathrm{m}^{2}\right)$ & $33,47 \pm 4,70$ & ns. & $31,45 \pm 4,26$ & ns. & $33,88 \pm 7,4$ & ns. \\
\hline 6MWD (m) & $514,60 \pm 97,66$ & ns. & $549,97 \pm 57,20$ & ns. & $541,71 \pm 73,59$ & ns. \\
\hline Borg-skála értéke & $3,58 \pm 2,55$ & $p<0,05$ & $2,07 \pm 20,06$ & ns. & $2,50 \pm 1,95$ & ns. \\
\hline MET & $8,56 \pm 2,78$ & $p<0,001$ & $11,82 \pm 1,36$ & $p<0,05$ & $10,59 \pm 3,16$ & $p<0,05$ \\
\hline TEKG-idő (min) & $9: 59 \pm 3: 22$ & $p<0,001$ & $14: 54 \pm 1: 57$ & $p<0,01$ & $12: 48 \pm 4: 02$ & $p<0,05$ \\
\hline
\end{tabular}






1. ÁBRA. Az egyes csoportok betegeinek lakhely-vizsgálóhely távolsága. „A" = ambuláns intézeti rehabilitáció, „M" =mellpántos otthoni rehabilitáció, „O" = optikai szenzoros „okosórás" otthoni rehabilitáció



2. ÁBRA. Az egyes csoportok betegeinek heti dokumentált tréningaktivitás-adatai

$3,90 \pm 2,00$, az „M" csoportnál 25,09 $\pm 21,76,(<0,001$ vs. „A"). az „O"-ban $25,18 \pm 13,51 \mathrm{~km}$ volt (<0,001 vs. „A"). Az „O” és „M" csoport tagjainak adatai között nem volt szignifikáns különbség. Ahogy az ábrán látható, amenynyiben távmonitorozott tréning lehetőség nyitva áll a betegek elött, $10 \mathrm{~km}$-nél távolabbról egy beteg sem választotta a bejárós tréning lehetőséget.

Az egyes csoportok jellemző heti tréningaktivitását a 2. ábra mutatja. A dokumentált átlagos tréningidő a „A” csoportban 115,92 $\pm 55,54$, az "M"-ben 125,76 $\pm 99,01$, az „O”-ban 177,80 $\pm 113,98$ perc. Az ambuláns és mellpánttal otthonában monitorozott csoport között nem volt érdemi különbség a heti tréninggel töltött időben, míg az okosórával monitorozott csoportnál szignifikánsan hosszabb heti tréningidő volt dokumentálható.

\section{Megbeszélés}

A metabolikus szindrómás, magas kardiovaszkuláris rizikójú személyek esetében az életmódrendezés, azaz a fizikai aktivitás növelése, a kalóriabevitel visszafogása kulcsfontosságú. Bizonyított, hogy ezen évtizedek alatt kialakult életmódi szokások néhány perces, orvosi tanácsadással érdemben nem befolyásolhatók, 5-15 óra/fö szakértői időráfordításra van szükség ezen mély berögződések hatékony átalakításához (3-5). Az életmódrendezés egyik kulcseleme a rendszeres fizikai tréning gyakorlatának kialakítása. Klasszikusan a felügyelt fizikai tréningek helyszíne a fekvőbeteg- vagy ambuláns rehabilitációs ellátás. A felügyelet nélküli, otthoni tréning egy alternatíva, de a tréningvezetés, a visszajelzés hiánya miatt a tréningszintek felépítése ilyenkor erősen lelassul, ami limitálja a tréning eredményességét (7). A technológiai fejlödés ugyanakkor lehetővé teszi a tréning felügyeletét a beteg otthonában is $(8,9)$. Az otthoni felügyelt tréning megszünteti a földrajzi távolságokból adódó hozzáférési korlátokat. Amenynyiben a tréningfelügyelet aszinkron („store \& forward”) technológiával valósul meg, az aktív korú személyek időbeli hozzáférési korlátja is kiiktatható, ugyanakkor munkaidőn belülre rendezhető a felügyeleti tevékenység az egészségügyi személyzet részéről.

Saját beteganyagunk azt igazolta, hogy amennyiben a vizsgálatba vonáskor a betegek számára a választási lehetőséget megadjuk, akkor $20 \mathrm{~km}$-es távolság felett egy beteg sem választja az ambuláns tréningre való utazást, mindegyikük az otthoni monitorozott tréninget preferálja. Vizsgálatunkba a 10-20 km közti lakótávolságról egy beteg sem került beválasztásra a beteggyüjtés sajátosságai miatt, ezért csak a $10 \mathrm{~km}$ alatti lakótávolságról jelenthetjük ki biztonsággal, hogy a heti kétszeri bejárás idő- és költségráfordítása a betegek számára az otthoni tréning vállalható alternatívája.

Ugyan 10 km-es lakótávolság alatt a betegszám az ambuláns bejáró, illetve otthoni tréninget választók között arányában, érdemben nem torzult, az ambuláns bejárást választók magasabb kora azt sugallja, hogy az aktív, fiatalabb korosztályok inkább választják az időben aszinkron monitorozott otthoni tréninget, az időben nagyobb kötöttséget jelentő jelenlétalapú ambuláns tréninggel szemben. Ezen életkori különbség egy másik magyarázata lehet a fiatalabb korosztály nagyobb nyitottsága az informatikai megoldások alkalmazására, míg az idősebb korosztály inkább választja a technikai jártasság nélkül megvalósítható ambuláns tréninget. $\mathrm{A}$ bejárós és az otthoni tréningre kerülö csoportok életkori különbözőségét már más tanulmány is dokumentálta (10), míg más munkák ilyen eltérést nem tudtak igazolni (11).

A monitorozással dokumentált tréningidő vonatkozásában az irodalmi adatok divergálnak. Egyes munkacsoportok az otthoni tréning esetén szignifikánsan rövidebb tréningidőket találtak (10), míg mások az otthonában telemonitorozott csoportot írták le motiváltabbnak, akik több időt töltenek tréninggel, mint a kötöttebb bejárós csoport tagjai (12). Saját anyagunkon az otthoni tréning során legalább annyi tréningidőt tudtunk dokumentálni, mint a bejárós tréninget végzők körében, sőt az egyszerübben viselhető, karórás csoportban a tréningidő úgy a mellpántos, mint a bejárós csoport- 
hoz képest magasabb volt. A jelenség háttérében az egyszerübben használható csuklópántos rendszerhez való nagyobb adherencia állhat, hiszen az okosóra folyamatos viselése nem okoz gondot, míg a mellpántos rendszer folyamatos viselése kényelmetlen, a mellpánt felhelyezése - különösen hölgyek esetében - speciális infrastruktúrát, öltöző elérhetőségét igényli. A megvalósult és dokumentált tréningek idejéről sajnos nincs adatunk. Nem zárhatjuk ki, hogy a mellpántot viselők tréningjeik egy részének dokumentálását egyszerüen elhanyagolták, a monitorozás elindításának körülményesebb volta miatt.

Eredményeink alapján az egyszerü szívfrekvencia-ellenőrzésre épülő tréningmonitorozó rendszerek az ambuláns bejárós tréningek ígéretes alternatíváját jelenthetik. Ezen rendszerekkel támogatva legalább akkora tréningidő biztosítható a betegek számára, mint a dokumentált ambuláns bejárás során. A telemonitorozás ugyanakkor megnyitja a tréning lehetőségét földrajzilag távolabb élő honfitársaink előtt a rehabilitációs programokban való részvételre, illetve azon, aktív korú személyek részére, akik időpontütközés miatt esnének el a rögzített időpontú, személyes jelenlétre épülő rehabilitációs foglalkozásoktól.

További kiértékelést igényel annak meghatározása, hogy az ambuláns tréning során milyen eredmények érhetők el a betegek fiziológiai paramétereiben.

\section{Köszönetnyilvánítás}

A projekt az Európai Unió támogatásával, az Európai Szociális Alap társfinanszírozásával valósult meg, EFOP-3.6.1-16-2016-00008 és EFOP-3.6.3-VEKOP16-2017-00009.

\section{Nyilatkozat \\ A szerzők kijelentik, hogy az összefoglaló közle- mény megírásával kapcsolatban nem áll fenn velük szemben pénzügyi vagy egyéb lényeges összeütkö- zés, összeférhetetlenségi ok, amely befolyásolhatja a közleményben bemutatott eredményeket, az abból levont következtetéseket vagy azok értelmezését.}

\section{Irodalom}

1. Paré G, Jaana M, Sicotte $C$. Systematic review of home telemonitoring for chronic diseases: the evidence base. J Am Med Informatics Assoc JAMIA [Internet]. 2007 Jun; 14(3): 269-77.

https://doi.org/10.1197/jamia.M2270

2. Carrera-Bastos P, Fontes, O'Keefe, Lindeberg, Cordain. The western diet and lifestyle and diseases of civilization. Res Reports
Clin Cardiol [Internet]. 2011 Mar. [cited 2013 Jul 14]; 15 https://doi.org/10.2147/RRCC.S16919

3. Aveyard P, Lewis A, Tearne S, Hood K, Christian-Brown A, Adab P, et al. Screening and brief intervention for obesity in primary care: a parallel, two-arm, randomised trial. Lancet [Internet]. 2016 Nov; 388(10059): 2492-500. https://doi.org/10.1016/S0140-6736(16)31893-1

4. Lin JS, O'Connor EA, Evans C V, Senger CA, Rowland MG, Groom HC. Behavioral Counseling to Promote a Healthy Lifestyle for Cardiovascular Disease Prevention in Persons With Cardiovascular Risk Factors [Internet]. Behavioral Counseling to Promote a Healthy Lifestyle for Cardiovascular Disease Prevention in Persons With Cardiovascular Risk Factors: An Updated Systematic Evidence Review for the U.S. Preventive Services Task Force. Agency for Healthcare Research and Quality (US); 2014 [cited 2018 Sep 1].

5. Knowler WC, Barrett-Connor E, Fowler SE, Hamman RF, Lachin JM, Walker EA, et al. Reduction in the incidence of type 2 diabetes mellitus with lifestyle intervention or metformin. N Engl J Med [Internet] 2002 Mar 14. [cited 2017 Feb 26]; 346(6): 393-403.

https://doi.org/10.1056/NEJMoa012512

6. Alberti KGMM, Eckel RH, Grundy SM, Zimmet PZ, Cleeman JI, Donato KA, et al. Harmonizing the Metabolic Syndrome A Joint Interim Statement of the International Diabetes Federation Task Force on Epidemiology and Prevention; National Heart, Lung, and Blood Institute; American Heart Association; World Heart Federation; International A. Circulation [Internet]. 2009 Oct [cited 2012 Nov 15]; 120(16): 1640-5. https://doi.org/10.1161/CIRCULATIONAHA.109.192644

7. Rawstorn JC, Gant N, Rolleston A, Whittaker R, Stewart R, Benatar J, et al. End Users Want Alternative Intervention Delivery Models: Usability and Acceptability of the REMOTE-CR Exercise-Based Cardiac Telerehabilitation Program. Arch Phys Med Rehabil [Internet]. 2018 Aug 1 [cited 2018 Sep 23];

https://doi.org/10.1016/j.apmr.2018.06.027

8. Senger CA, Redmond N, Lin JS. Behavioral Counseling to Promote a Healthful Diet and Physical Activity for Cardiovascular Disease Prevention in Adults Without Known Cardiovascular Disease Risk Factors: Updated Systematic Review for the U.S. Preventive, Services Task Force. Evidence Syn [Internet]. 2017 [cited 2018 Sep 1]. https://doi.org/10.1001/jama.2017.3303

9. Alwashmi MF, Mugford G, Abu-Ashour W, Nuccio M. A Digital Diabetes Prevention Program (Transform) for Adults With Prediabetes: Secondary Analysis. JMIR diabetes [Internet]. 2019 Jul 26 [cited 2019 Aug 10]; 4(3): e13904. https://doi.org/10.2196/13904

10. Piotrowicz E, Baranowski RR, Bilinska M, Stepnowska M, Piotrowska M, Wójcik A, et al. A new model of home-based telemonitored cardiac rehabilitation in patients with heart failure: effectiveness, quality of life, and adherence. Eur J Heart Fail [Internet]. 2010 Feb [cited 2011 Oct 16]; 12(2): 164-71.

https://doi.org/10.1093/eurjhf/hfp181

11. Stickland MK, Jourdain T, Wong EY, Rodgers WM, Jendzjowsky NG, MacDonald GF. Using Telehealth Technology to Deliver Pulmonary Rehabilitation to Patients with Chronic Obstructive Pulmonary Disease. Can Respir J [Internet]. 2011; 18(4): 216-20.

https://doi.org/10.1155/2011/640865

12. Zampolini M, Todeschini E, Bernabeu Guitart M, Hermens $H$, Ilsbroukx S, Macellari V, et al. Tele-rehabilitation: present and future. Ann Ist Super Sanita [Internet]. 2008; 44(2): 125-34. https://doi.org/10.1097/AIA.0b013e3181950078 